\title{
A Vision on More Sustainable Eastern European Rural Areas. Some Lessons from Romania ${ }^{1}$
}

\author{
Alexis Sancho ReINoso and Ede Márton Kovács, both Vienna [Wien]*
}

with 2 figures in the text

\section{Content}

Summary 345

1 Introduction. 346

2 Turning rural areas smarter: eight challenges (and eight pathways to face them).....

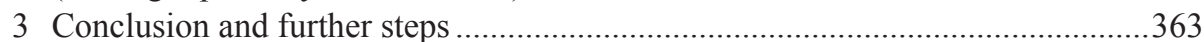

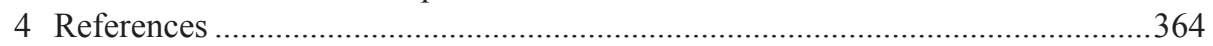

\section{Summary}

In this paper a vision on the future of rural areas in Eastern Europe is presented, based on the preliminary results of a bilateral research project on local rural development in Romania and Austria. The argument's starting point is that the 'smart'

\footnotetext{
$1 \quad$ The authors would like to express their gratitude to the whole research team of the bilateral project "Examples of successful regional development in Romania's and Austria's rural space. Research into factors of their success and transfer possibilities to other areas in these countries", and particularly to Prof. Peter JoRDAN (Austrian team leader). Other members of the research team were Kinga Xénia Havadi-Nagy (Romanian team leader), Antonia Carole, Marius Cristea, Oana Ramona Ilovan, Zoltan Maroșı and Thomas Zametter. The research project was funded by the Romanian National Council of Scientific Research in Higher Education (CNCS UEFISCDI) and the Austrian Agency for International Cooperation in Education and Research (OeAD).

* Alexis Sancho Reinoso, PhD., Centre for Global Change and Sustainability, University of Natural Resources and Life Sciences, Borkwokskigasse 4/4, A-1190 Vienna, Austria; email: sancho.reinoso@gmail.com; Mag. Ede Márton Kovács, Széchenyi Programiroda Nonprofit Kft, Verő József út 1, H-9400 Sopron, Hungary; email: ede.kovacs@gmx.at
} 
label currently in fashion (e.g. 'smart cities') can be a useful approach for rural areas to address the manifold current global challenges. Nonetheless, this might only be true if it is assumed that certain societal transformations are required to reconcile the way societies cope with their natural environment. This hypothesis is developed in the body of the paper, which is structured in eight issues (energy crisis, growth, social capital, diversification, identity, EU policies, cultural landscapes, spatial planning) that determine whether a given area can succeed in such challenge. Based on lessons learned from three surveyed Romanian municipalities, it is argued that in order to become 'smart', rural areas should become more resilient, local-based and authentic, and that this can only be achieved by questioning certain hegemonic discourses on how the above-mentioned eight issues should be tackled.

\section{Introduction}

\subsection{Theoretical background and aim}

Regardless of their manifold and deep differences, European rural areas (as well as any other place worldwide) are inevitably shaped by a global crisis with multiple symptoms (Del Moral 2012): climate change, peak oil or "peak everything" (HeINBerg 2007), poverty, famine, unemployment, loss of biodiversity. As it has been argued by a number of scholars at least since the 1970s, following the legacy of the MEADows' report (MEADows et al. 1972), such global crisis can ultimately be interpreted as the consequence of an unbalanced relationship between societies and nature. Thus, only by addressing this issue as a whole (this is, avoiding the Cartesian division between nature and culture) firm steps towards the keenly awaited sustainability can be made.

How can such discussion be developed in the context of rural areas in Eastern Europe? This paper's starting concept is the adjective smart, since it is being used by many policy makers and practitioners worldwide as one way to respond to the abovementioned current challenges. Even though there is no standard definition, 'smart' has been associated to the ability of becoming more efficient in different dimensions (economy, people, governance, mobility, environment, and living - GIFFINGER et al. 2007). Being originally used in urban environments ('smart cities'), nowadays there is a number of institutional initiatives using the term smart rural areas in Europe. ${ }^{2}$ Here this concept is assumed as a means to foster those societal or socio-ecological transformations (BRAND \& BRUNNENGRÄBER 2013) that are needed to tackle the abovementioned crisis. To do so, a profound rethinking of the way humans are organised in societies is required.

2 For instance, the European Commission supports the "Strategies for Smart Specialization-S3" platform. One of the topics deals with rural innovation and puts the emphasis on smart rural areas (see http://s3platform.jrc.ec.europa.eu/rural). 
In this paper a vision on how Eastern European rural areas may address the abovementioned scenario of multiple crises is presented, based on the above-announced approach and taking into account the similarities and differences with respect to Western Europe. The ultimate goal is to contribute to an operational action plan for European rural areas. The body of the paper is structured into eight issues showing how comprehensive the picture is: Here the global energy crisis, the economic growth imperative, the need for diversification of rural economies, the fostering of their social capital, the role of the EU, the status of the cultural landscapes, identity issues, and the orientation of activities like spatial planning are examined and their effects and consequences for Eastern European rural areas are assessed on the basis of three case studies in Romania.

\subsection{The case studies}

The places for the three case studies were selected in the framework of a bilateral research project titled "Examples of successful regional development in Romania's and Austria's rural space. Research into factors of their success and transfer possibilities to other areas in these countries", carried out in 2014 and 2015 by a team of nine researchers from both countries. Whereas the three places in Romania were visited during a field trip in summer 2014 (Fig. 1), the field trip in Austria will take place in July 2015. Therefore, this paper can present only preliminary results of the project.

Rimetea/Torockó is a 1,089 inhabitant (data as of 2011) municipality located in the Alba County. Two populated places are part of it, Rimetea/Torockó - a former mining town, and Colțeşti/Torockószentgyörgy - a farmers' village. Rimetea/Torockó was first documented in 1257 under the name Toroczkó. As a part of the Hungarian Kingdom it was the most western Szekler settlement in Transylvania [Ardeal]. The Szeklers moved there in the $13^{\text {th }}$ century to support local Hungarians against the Tatar invaders. After their defeat, the Szeklers were rewarded with pastures and settled in Torockó. Due to a population decline after the Tatar and Kun invasions in 1291, German settlers were also invited to the town.

Rimetea/Torockó is known today for the "Rock of the Szeklers" [rom.: Piatra Secuiului; hun.: Székelykö], a mountain that lets the sun get up twice at dawn. The town has become a Szekler cultural centre and has gained notorious popularity (and touristic relevance) after winning the "Europa Nostra Award" in 1999 for preserving it's former architectural shape and heritage. ${ }^{3}$

Viscri/Deutsch-Weißkirch (hung. Szászfehéregyháza) is a small village (467 inhabitants in 2002) belonging to the municipality of Bunesți (Braşov County). The

Source: http://www.torocko.eu/tortenelem.html. 
first building of Viscri/Deutsch-Weißkirch originates from around 1140, when Szeklers built a small church on the place, where the Saxon fortified church is located today. The church was taken over by the Saxons in the year 1185 and the Szeklers were forced to settle further north. Since most of the Saxons emigrated to Germany in the $20^{\text {th }}$ century, Viscri/Deutsch-Weißkirch has today a Roma majority with a few Romanians and 20 Saxons left. ${ }^{4}$

Marginea is a small town in the Suceava County, in the historical region of Bucovina. It is a second-order regional centre located at main touristic routes and well-known for its black pottery. The famous monastery of Suceviţa (one of the most prominent touristic attractions in the whole region) is located very close to Marginea. The place is situated near to the Eastern Carpathians [Carpaţii Orientali] and the Ukrainian border; thus, its peripheral situation is quite evident. The commune has around 8,500 inhabitants (data as of 2011), but its population is currently declining due to migration to Western Europe. Marginea was first mentioned in $1455 .^{5}$

Figure 1: The field trip from Vienna [Wien] to Cluj-Napoca and the three places investigated (Base map: Google Maps)

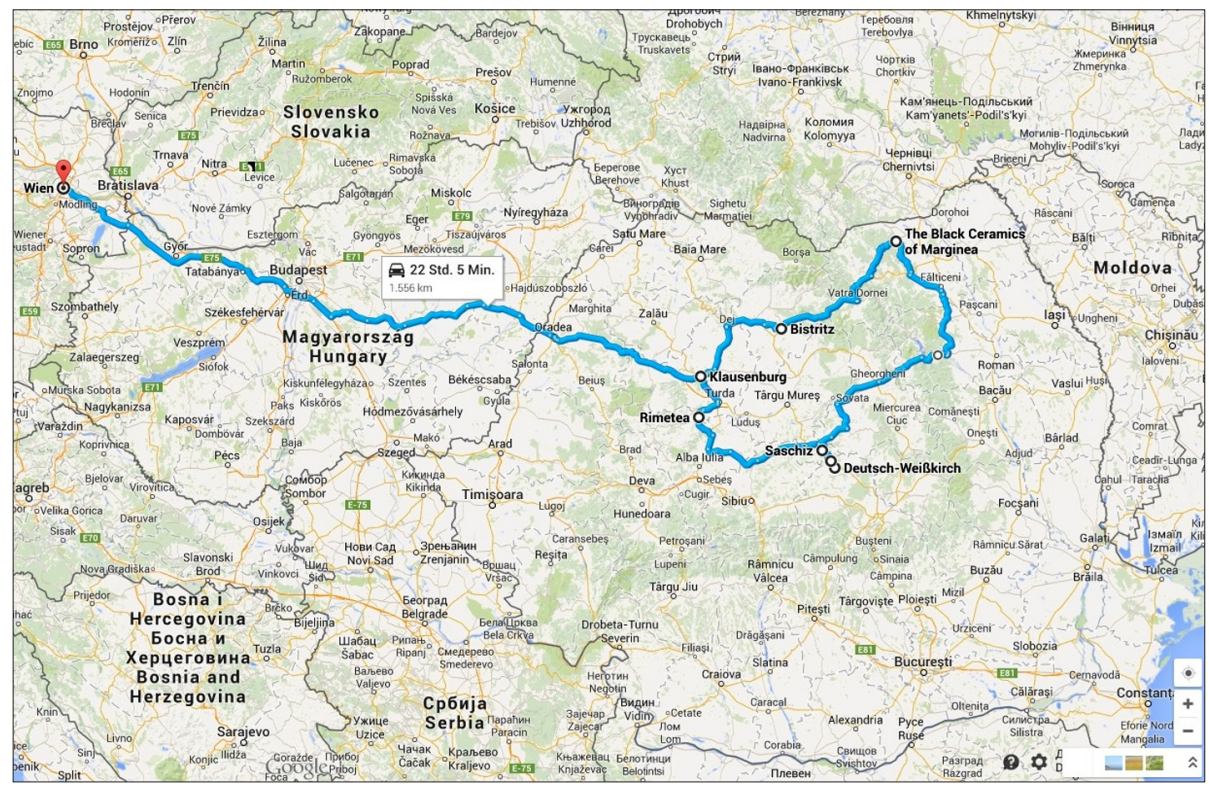

Source: http://www.viscri125.ro/ii

Source: http://ro.wikipedia.org/wiki/Comuna_Marginea,_Suceava 


\subsection{Methods and approach}

The research methods applied during the field trip include both in-depth semistructured interviews with selected persons and 'focus-group' discussions with locals. Six people were interviewed, including representatives of public authorities (two mayors - interviews $2 \& 4$ ), a stakeholder of the civil society (Interview 5) as well as representatives of non-governmental organisations (interviews 1 \& 3). An additional, unexpected interview took place with a local citizen in Viscri/Deutsch-Weißkirch (Interview 6). The interviews and the focus-group discussions have been numerated (1 to 6 and 1 to 3 , respectively) in a sheer chronological order.

The three focus-group discussions (one in each of the places investigated) were conducted in the format of qualitative, open and interactive interviews with a group of local stakeholders. Interviews and focus-group discussions were conducted in Romanian, Hungarian, German or English.

Thus, this paper is mainly based on experiences during the field trip as well as lessons learned from interviews and focus-group discussions and reflects exclusively the opinion of the two authors. These are an 'outsider' (Alexis SANCHO REINOSO originally comes from Catalonia [Cataloña/Catalunya] in Spain and has partially developed his research in Austria, where he now lives.) and a kind of 'outsider-insider'. (Ede KovÁcs was born in the Szeklerland [Székelyföld], a Hungarian-speaking area in Romania, to which he is still linked, although he is living in Vienna since his childhood.)

\section{Turning rural areas smarter: eight challenges (and eight pathways to face them)}

How can rural areas become smart (or smarter)? In this section the paper's main argument is developed, taking as a reference eight issues, which summarise the extraordinary complexity of the spatial and territorial framework any rural area is exposed to. They are: the current energy crisis (Section 2.1); the (economic) growth imperative (according to the neoliberal system) (Section 2.2); the role of social capital (Section 2.3); the need for diversification (Section 2.4); those issues related to collective identity (Section 2.5); the role of European Union (EU) policies (Section 2.6); the management of cultural landscapes (Section 2.7); and spatial planning activities (Section 2.8). Inspired by the testimonials from the field trip, the authors suggest ways to face each of these eight challenges. Key words related with such ways are included in all sections' titles with an exclamation mark besides the above-mentioned general issues (the latter are followed by a question mark). 


\subsection{Energy crisis? Resilience!}

As Europe is increasing its dependence on external energetic inputs (WoRLD ENERGY CounCIL 2008), serious consequences in the way rural areas are organised might appear in the near future. Because of the extreme importance of fossil fuels in the way our current societies are organised, this issue is presented as the first one, since it somehow conditions the others.

In this context, facing energy crises is indeed not straightforward. What is primarily needed is to increase the degree of flexibility and adaptation. In other words: a crucial strategy to design and implement real alternative policies to make our societies more resilient. Shortly defined, resilience is the ability of a given system to cope with change (Wieland \& WALLENBURG 2013). In this paper the term system is applied to local communities like a municipality or a group of them. The less dependent on fossil fuels they become, the more resilient they will be, since fossil fuels determine many aspects of life (nourishing, mobility, shelter, leisure, and so forth).

The authors speculate with the idea that Romanian rural areas might be more resilient than other places in Western countries in the event of a fossil fuels' scarcity, at least if one takes into account basic supply: for instance, short fresh products' circuits are more frequent in 'poor' rural areas than in Western Europe, where processed products and fruits \& vegetables (many of them from overseas) are available daily in supermarkets at costs of cheap fossil fuels, also in rural areas. Organic agriculture is key to increase the resilience degree because it drastically reduces such dependence. Having experienced the way local farmers' networks are being established in the places visited during the field trip, we argue that this activity has a huge potential in Romania. However, massive hurdles (related to bureaucracy, property structure, certification costs and farmers' mind-set) have to be overcome, as it was stated in Interview 3. This concerns both local population and public authorities.

There are of course further issues (related, e.g., to social cohesion and networks) that should be taken into account when talking about resilience. Under such perspective, and after suffering a deep restructuring process steered by the central state, one can figure out that many Romanian areas possibly have a weak degree of social cohesion and a too rigid institutional framework compared to Western European countries.

What lessons can be learned from the three examples selected? The case of Rimetea/Torockó and Colțeşti/Torockószentgyörgy is extremely interesting in terms of resilience and energy-adaptive local systems. Their location side by side in a common municipality has determined close relationships in several fields, including infrastructures (They share the same canalisation network.), education (common secondary school), or social issues. (There are different community building trusteeships.) The most illustrative aspect in this regard is the informal partnership between both places, which is shaped by complementary economic activities: Rimetea/Torockó has developed a touristic appeal on its mining past and the architectural heritage of this period as well 
as its scenic uniqueness. Colțeşti/Torockószentgyörgy profits from its location in the fertile section of the valley and developed intensive cultivations, including flower growing in greenhouses. Mutual linkages allow an exchange between both places:

\begin{abstract}
"There is an economic cycle within the two places. Torockó buys the agricultural products and food produced in Szentgyörgy to provide for the needs of the touristic activities. The farmers from Szentgyörgy bring their consumables to the market place of Torockó and sell it there. So every village can profit from tourism. This system works very well." (Interview 2)
\end{abstract}

Another 'best practice' example is the ecological sewage system implemented in Viscri/Deutsch-Weißkirch (and planned in other places of the municipality of Buneşti), based on a biological process that cleans waste water through the action of microorganism, resulting in compost and clear water output. This project's contribution to increasing local resilience is self-evident as well as its relevance for further issues addressed in this paper. Another important aspect of this project is its clear transfer potential, demonstrating that innovative solutions towards socio-ecological integration are also possible with small budgets.

Marginea shows that such tight relationships are of course the combination of several factors that might not always be present or just not able to be combined in order to obtain this kind of symbiosis in terms of resilience. In Marginea are two relevant economic activities (tourism and forestry) linking it with neighbouring municipalities, particularly Suceviţa. Both municipalities are therefore strongly influenced by tourism, the effects of which can, however, not be compared (in terms of success and positive trade-offs for the local population) with the case of Rimetea/Torockó or even Viscri/ Deutsch-Weißkirch. Forestry, in turn, is not better integrated in both villages than tourism, as we learned from the focus-group discussion. This is a vital resource in the above-described scenario regarding energetic issues and might play a central role in the future of the village. Marginea's woodland is currently being exploited by foreign (i.e. Austrian and Swiss) companies. Marginea plays, however, another important role for its wider region: a regional food market is run for ten years and an ambitious development programme in several economic sectors has been officially established.

\title{
2.2 (Economic) growth and neoliberalism? Sufficiency!
}

Ultimately, (almost) all rural areas in Europe struggle with the same problems, namely structural disabilities when coupling with the economic system. They are not competitive. However, one can find relevant differences between Western and Eastern European countries regarding this issue. Romania constitutes a very good example to understand such differences, since it was one of the countries, which was most marked 
by the Communist system. These countries now lack national compensatory measures concerning the development of rural areas, since their central areas are not competitive enough in the global context to be able to foster rural development. In Western countries (like Austria) the situation is quite the opposite. They are competitive; their economy is stable, so the funding of rural initiatives is granted. How the status quo will change in rural areas of the developed world after the crisis of the neoliberal economic system will show how effective and sustainable these countries deal with their 'cradle of civilisation' discourse.

Growth, in particular economic growth, is the ultimate driving force of the current hegemonic socio-economic system, i.e. neoliberalism. As an economic model, the neoliberal goal is endless growth by establishing a free market without any kind of restrictions. The assumption behind is the so-called homo oeconomicus, according to whom an individual is supposed to act and make decisions of rational nature exclusively, only based on his own individual benefit. ${ }^{6}$ What is argued in this paper is that rural areas (and, as a matter of fact, any territory) cannot fit in such a logic. Traditional rural areas have always lived self-sufficient, sustainable and resilient. But these three adjectives are not acceptable under the modern neoliberal paradigm, where declining is equal with system failure.

Behind both traditional and modern socio-economic systems are valuable tools for society. The key question is what can be done not to destroy rural areas by forcing them into competitiveness issues, where rural lifestyle cannot survive. At this point we should distinguish between rurality as a spatial entity and those socio-economic features that have been established in such areas. We will concentrate on the second issue.

Why should mankind preserve traditional rural lifestyle in the $21^{\text {st }}$ century, when demographic statistics still show a migration flow from rural to urban areas? The answer is simple at first sight. Everybody loves nature. But is that enough? If we look at the issue in a more comprehensive way the first key word is balance.

It becomes pretty apparent that the developed Western civilisation has established a highly unbalanced relationship with nature beginning with the industrial revolution. There are huge gaps concerning resource consumption and reproduction of physical resources, what is called "social metabolism" (FISCHER-KowALSKI et al. 1997). A similar problem pose spatial and human capital-related resources, since consumption of resources does not anymore focus on the ability to reproduce resources concerning human capital but concerning exclusively capital and profit increasing. Neoliberal 'values' (i.e. immediacy, profit maximisation at all costs) have had catastrophic consequences in life, and as a result, human capital is only measured according to monetary standards. Nevertheless, as long as rural areas will remain living areas and

$6 \quad$ From an interview with Milton Friedman (on January 10, 2000): "The most important single central fact about a free market is that no exchange takes place unless both parties benefit." (Source: http://www.pbs.org/wgbh/commandingheights/shared/minitext/int_miltonfriedman. html\#1) 
resist becoming places to make profit, this system will not be able to destroy them as living spaces.

In order to solve this dichotomy, efforts to delink the notion of development from the growth imperative are required. To do so, a wide debate concerning what is called sufficiency has to be fostered at cultural, social and political level. This should run parallel to the generally recognised need on making progress in those technological issues that increase the degree of 'efficiency'. Sufficiency has been defined as the logic of "consuming the right quantity of material goods and services, a quantity that is just necessary and sufficient for optimal health, well-being and happiness, escaping both the Charybdis of underconsumption (poverty) and the Scylla of overconsumption" (Boulanger 2010).

An appropriate way to do that is to establish local economics that supply the local and regional cycle with the products it needs. These are not only physical products but the authentic way of life in rural areas, authentic tourism. The open question in other words is how to 'recreate balance', physically and psychologically. To some extent, our field trip presented us such solutions. There are locally based economic cycles in Rimetea/Torockó and sustainable, self-reproducing wastewater systems in Viscri/Deutsch-Weißkirch and, last but not least, traditional products produced with old techniques in Marginea, i.e. black pottery.

If the link cannot be established, parallel worlds, i.e. modern versus traditional, representing two antagonistic lifestyles, will consolidate. This cannot be an aim to be desired. Urban dwellers are living in a wrong feeling of convenience, thinking that everything works in the city but deny the "slow and boring" life in a village. However, what seems clear is that a city does not work without the countryside, but not viceversa: Cities are completely dependent on what is extracted in their catchment area in order to provide themselves with material and non-material inputs to allow their daily reproduction, while rural systems might become more independent (if they overcome their dependence on fossil fuels), since they have strategic resources like land.

One of the interviews showed this concern in Viscri/Deutsch-Weißkirch: "Mayors are inclined to rent or sell communal pastureland, because they need the money for projects. But people should not be deprived of the opportunity to continue their traditional life in the countryside and forced to migrate to cities." (Interview 5) We cannot destroy those elements still working. We all know how difficult it is to reintroduce certain activities in our society because they are not convenient anymore. (Who is going to work in agriculture again after having experienced the conveniences of living in urban environments?) But there are thousands of examples of people living in rural areas and from agricultural activities, and they just want to be able to keep living this way.

In this respect the authors dare to say that Viscri/Deutsch-Weißkirch is a truly pioneering case. And linking it to the above-mentioned great challenges our civilisation is facing, the suggestion is taking advantage of the concept of sufficiency (or the 
way to decouple our activities from energetic and material resources consumption) to reconsider the idea of (rural) development taking different perspectives than the classical one linking development with (economic) growth. It is time to opt for another kind of development as the main driver of individual and collective progress. Can simplicity (= sufficiency) become a key value for resilient rural areas? The following statement hits very much this point: "We don't need more tourists. We earn money enough. But people always want more.” (Interview 5)

Ultimately, the key factor to become sufficient might be time. Time is an extremely scarce resource in our current society, and reducing work time may be the way to obtain more room for investing personal time in activities that remain outside the market economy (i.e. remunerated work), but will guarantee our well-being. They include the coverage of basic needs related to care (of ourselves, of our children, of our elderly), but also to other vital needs that provide truly prosperity (JACKSON 2009). Here the concept of prosumer (the result of mixing both dimensions of an individual as PROducer and conSUMER suggested by M. MCLUHAN already in the 1970s) should be born in mind.

\subsection{Social capital? Social entrepreneurship!}

One of the most frequently used arguments when referring to the rural areas' ability to escape marginalisation is social capital. Weak social structures and local communities may neutralise any attempt to enforce an area through economic inputs (WIESINGER 2007). But what generates social capital? What factors can boost vibrant local rural communities?

The ADEPT Foundation ${ }^{7}$ is a key actor in the so-called Târnava Mare Region (a non-administrative development region that includes Viscri/Deutsch-Weißkirch). According to the interviewed staff member (Interview 3), the foundation originally aimed to develop projects to conserve biodiversity. However, when they started their work at ground they soon realised that this goal was not achievable without involving locals and particularly farmers. The story of ADEPT is, therefore, a story of implementing projects for and with locals. An example of its projects shows that:

"We're developing a project offering high-yield cows to low-income families interested in starting up cow breeding. The project is working in other parts of Romania with an association working with Gypsies. Those families receiving the cow are encouraged to use milk collection points. The cow owners have to demonstrate that they are able to maintain the animal. ADEPT offers training and equipment to test the milk. We also advise them to improve milk quality by offering very simple know-how (like 'tricks' from popular wisdom). They are smart solutions that can be as effective as high technical ones." (Interview 3)

$7 \quad$ http://www.fundatia-adept.org/?content=default. 
What makes this foundation credible is that its headquarters are located in the region, and that staff members live there. The role of local/regional non-governmental actors is one of the success stories in Viscri/Deutsch-Weißkirch, but also in Rimetea/ Torockó with the Mihai Eminescu Trust (MET). ${ }^{8}$ They influence local prosperity by re-inforcing a bottom-up perspective.

Beyond institutions, civil society itself has to play a decisive role to generate social capital. In this regard, Viscri/Deutsch-Weißkirch reveals the importance of social entrepreneurs, i.e. initiative individuals able to bring up changes in a community. ${ }^{9} \mathrm{~A}$ lady there decided some decades ago to work for increasing the community's living standards. She has been able to mobilise resources from outside, but particularly from inside. The latter are related with the locals' commitment rather than with financial issues.

What we argue here is that these kinds of testimonials do not necessarily have to be that exceptional. Almost everywhere there is someone, who might be in a good position (e.g. have authority in the community due to their profession) to do the first step. This leads to self-politicisation and can end up in different strategies. In the example of Viscri/Deutsch-Weißkirch, one finds an engagement in local politics, but also a networking effort with external peers or actors interested. The decisive step in this empowerment process is to establish a critical mass that is strong enough to lobby for its own interest, i.e. deciding upon its future by managing their village, their resources, their territory.

At this point, also some doubts regarding the extent to which individual leadership has evolved into collective leadership in Viscri/Deutsch-Weißkirch may be raised. The emphasis on the issue on the 'succession' of the village leader (Interview 5) adds additional uncertainty on that. What becomes apparent is that an individual hardly can change anything, rather a group. It is not necessary to involve the whole population, not even the majority: "Not all the villagers attend village meetings. There is also a group constantly denying cooperation. These are people, who are well off and do not need support. The meetings are mainly attended by those, who have no work and who need support." (Interview 5)

In any case, strong social cohesion is the breeding ground for the emergence of social entrepreneurs, but it might not be enough. Trust between neighbours is critical, as the examples of Rimetea/Torockó and Colţeşti/Torockószentgyörgy show: "The people of Torockó are more or less only buying from Szentgyörgy because they know the people and they know what they are going to get." (Interview 1) Nevertheless, we could not identify any local leadership there, in contrast to Viscri/Deutsch-Weißkirch. In the latter place the villagers' 'feeling of ownership' seems to be strong, at least if one listens to the village leader:

\footnotetext{
8 http://www.mihaieminescutrust.ro/en/.

9 We were inspired by the ASHOKA definition of social entrepreneur (https://www.ashoka. org/social_entrepreneur).
} 


\begin{abstract}
"A major problem today is a loss of the local community's capacity to control the development. This is instead increasingly driven by external forces. To counteract, they use the quiet months from November to April, when no guests are present, for internal communication. Its main purpose is to include everybody into the development. Everybody should benefit from the village's development, to make him/her resistible against 'external temptations'. The story of a house owner, who had sold his house at a high prize to somebody from Bucharest and bought a house at a much cheaper prize in a neighbouring village, e.g., serves as a deterrent example" (Interview 5).
\end{abstract}

Regardless of important differences, Rimetea/Torockó and Marginea have one common aspect related to social capital: Both of them have huge potential if they manage to enforce internal cohesion and informal networks. In Rimetea/Torockó, house owners could cooperate to manage tourist demand and become more independent from external tour operators (Focus Group 1). In Marginea, the population size undoubtedly increases complexity, but this is at the same time a valuable asset, especially because the village is to some extent (and despite its recent demographic loss) capable to attract new young residents and re-migrants, who come back to their home town after having spent some years abroad (Focus Group 3) - a trend in many other rural areas in Romania, according to other testimonials (Interview 3).

\title{
2.4 Diversification? Reducing market size!
}

Economic diversification has been (and probably still is) the 'official' model to escape from the productivist paradigm (ILBERY \& Bowler 1998) that dominated agricultural policies after World War II and that started its decline after the first oil crisis. However, decades after paradigm change it can be argued that most of the rural (and particularly) mountain areas have not managed to escape the dynamics of marginalisation just by applying such strategy. The main reason for that is probably that the countryside has moved from a space designated to be the food provider into a space that offers commodities to the urban population in search for 'nature', for the 'authentic' (LAPPING 2006). According to the discourse of post-productivism, the so-called primary sector can survive only if it is linked to tourism. What has often happened is that the latter has become a kind of panacea, the main (and in many cases) only way to secure the income of households (and ultimately regions). Paradoxically, it has become a monoculture. But how has tourism developed in our cases?

Tourism plays a decisive role in all three cases, with divergent experiences in each one. While Rimetea/Torockó is purely touristic, Viscri/Deutsch-Weißkirch is only partly touristic and Marginea even less influenced by this activity. Despite of the dominating role of tourism, Rimetea/Torockó has managed to properly integrate tourism in its local economy. Tourism contributes to the maintenance of the built cultural heritage and provides significant income for many households. 
In Viscri/Deutsch-Weißkirch, despite of the attractiveness of the village and particularly of its fortified church, tourism is confined to the very specific segment of visitors seeking a peaceful place far away from any 'stress' and ready to miss any kind of comfort (measured by 'Western standards').

In Marginea, tourism plays a secondary role in spite of its well-known glazed black pottery. It takes some advantage of the close and famous monastery in neighbouring Suceviţa. However, recent developments (wild urban sprawl due to new homes of commuters and migrants) have contributed to a degradation of its attractiveness.

How could a rural area become more autonomous in tourism? Here we argue that local economy should become more integrated by seeking viability in the socioecological system in which it is embedded. Increasing integration necessarily means making those material and energetic cycles closer and, thus, keeping market size small. This does not mean local autarchy: (social) entrepreneurship is crucial for making local communities flourish and creating new markets for new products might be a good strategy. The main point here is to find the right scale for every activity, always prioritising the immediate environment as the most suitable reference. This is what already scholars like E.F. SCHUMACHER argued in the 1970s (SCHUMACHER 1973), what disciplines like Ecological Economics demonstrate and what might fit with demands of the civil society. ${ }^{10}$

Coming back to our cases, in this context Rimetea/Torockó and Colțeşti/ Torockószentgyörgy have to be highlighted again. The case of Viscri/DeutschWeißkirch shows that much work has to be done to better integrate agriculture with other economic activities. We learned that many households are highly dependent on public subsidies connected with sheep keeping, to the extent that this activity has become an end in itself, i.e. only to receive these payments. This all seems highly contradictory, since the most commercialised local product are home-made wool socks. ${ }^{11}$

This brings us again to agrarian activities and their role in locally integrated economies. The case of the Târnava Mare region shows how this integration might work by networking actors at the regional level. Farmers' associations are fostered through sharing machinery and common facilities like a jam processing plant and milk collection points. Regarding the latter, we highlight the following example:

"Milk collection points used to belong to companies, which of course put a big pressure on prices. Now all facilities in the point (building and machines) belong to the commune and are freely leased to the associations. So, if a company wants to establish prices they have to negotiate. This mechanism empowers farmers." (Interview 3)

\footnotetext{
10 See the work of the "Association for the promotion of the economy for the common good" (Source: https://www.ecogood.org/en).

${ }_{11}$ See the Viscri/Deutsch-Weißkirch socks' website (only in German): http://viscrisocken. insopro.org/.
} 
In order to understand the importance of these developments it has to be reminded again that they occur in a former Communist country like Romania, where collectivisation caused traumatic experiences among the rural population, who in many cases has become highly reluctant to re-enter farming associations.

Beyond agriculture, probably the flagship networking initiative in this region is the development of a 95-km-long bicycle trail from the famous Saxon city of Sighişoara/Schäßburg to Viscri/Deutsch-Weißkirch. This project connects several municipalities by sharing a common strategic infrastructure that attracts well-educated people with a high respect for the human and natural environment. The trail fosters local population networks by responding to the tourism-driven demand on quality home-made products, including accommodation and local food.

\subsection{Identity? Respecting minorities!}

This issue concerns two dimensions that will be developed in two separate sections.

On the one hand, respect by official authorities and particularly by the central state administration for the variety of space-related cultural identities including minorities - Hungarian in the Szeklerland, Roma or Gypsies spatially widespread, is needed. It is quite usual to hear in Transylvania that the Romanian state is not able to cope with the reality of its territory, i.e. its multicultural character.

Following Á. TAMÁsI's statement in the 1930s ("We live in this world to be at home in it somewhere."), collective identity (cultural, ethnic or even local) is strengthening communities by the issue of 'belonging'. Sharing roots, language, traditions and a certain space is important for the individual as well as for the community. It binds a group of people together.

An interesting example of how communities are strengthened by collective identity is the situation in Rimetea/Torockó. The vice-mayor of the village: "We are a Hungarian island in the Romanian ocean here. We have to look at things differently." (Interview 2) The Hungarian and Szekler flags all over the town show this collective understanding about the origin and the heritage of this place.

Viscri/Deutsch-Weißkirch, on the other hand, is quite the opposite example, where the sense of a new collective identity is probably not yet developed after it has undergone profound demographic changes. Roma people moved into the empty houses of the Saxons, who migrated to Germany in the second half of the $20^{\text {th }}$ century. The main discourse is about coping with the status quo in order to make the village work sustainably, what it does quite well according to local testimonials. Regarding the issue on identity, the following statement is quite indicative: "By repairing their village, people actually make it their own - even though it is the heritage of somebody else." (Interview 5) 
In Marginea the overwhelming majority is ethnically Romanian. Despite of this homogeneity, the need to show a common collective identity, i.e. to solve the question "Who are we?" seems to be at least as relevant as in Rimetea/Torockó and Viscri/ Deutsch-Weißkirch. The quite impressive statue of "Stephen the Great" (whose legacy is controversial in historiography) in the mayor's office illustrates this clearly enough. This can be deduced even from several traditional products that are regarded as cultural heritage (e.g. black pottery). The focus-group discussion revealed another interesting aspect that can also be related to the importance of the sense of 'belonging': labour migration. This is a big issue in the area and provides a living for a lot of families. The earned money is in many cases invested at home, e.g. for building a home right next to the parental house. The villagescape is intensively shaped by this phenomenon.

Respect for the bricks of this pretty sustainable cultural and economic mix that has survived for a very long time has to be re-established in order to make it work. This kind of respect requires an interethnic and interregional discourse on history to gain the most value out of it and the political will to make it happen.

The second dimension of respect concerns the milieu of rural citizens. Rural areas are supposed to be respected by public authorities. There are decisions to take in order not to destroy the local rural community, but let them participate in market processes. Rural communities have to be compensated by disparity equalisation payments and other initiatives to re-establish a balance.

Also local entrepreneurs have to be encouraged to act in areas, where Communist dictatorship ruined bottom-up initiatives for decades. A statement from Viscri/DeutschWeißkirch:

"People usually complain about their mayors. But they let them be bought for elections, since they are poor. They also do not insist on their rights opposite the mayor or remind him of his promises. He is too much an authority for them and people are too fearful. They have a mentality of subjects. Rural citizens are not aware of the fact that politicians have the mandate to serve them and are paid by their taxes." (Interview 5)

A very interesting statement depicting successful, non-discriminating policies affecting the Roma minority also came from Viscri/Deutsch-Weißkirch: "The Mihai Eminescu Trust takes no special measures for the Roma. All measures comprise the entire community of the village - Roma are just the ones, who benefit most. Would these measures be titled Roma projects, they would not be accepted as much as they are." (Interview 5) This connects both dimensions addressed in this section - cultural as well as rural identity.

However, the classical example when addressing relationships between administration and local population in rural areas is bureaucracy. The following excerpt from Interview 3 illustrates the problem: 
"Legislation was always a hurdle, we have tried to fight from the very beginning. For instance, for jam producers the legislation was as follows: Doesn't matter the size of the factory, everybody should respect the same rules regarding facilities. We argued that this was not normal not to differentiate between big companies and small ones (as it is everywhere else in the EU). Finally it took one year and a half to change legislation, even the EU was on our side. We didn't obtain any feedback from official authorities when this was required, e.g. by filling up questionnaires. And to make matters worse, informal relationships at the highest political level may also play a role, either positive or negative. Once we met by chance an influential politician, who felt committed to our struggle against bureaucracy. He stated that if something is supported by political will «it can be changed in one day»". (Interview 3)

A last (but not the least) issue that goes against respect is corruption, reflected e.g. by an interview in Viscri/Deutsch-Weißkirch: "To transfer electric transmission lines underground was once a proposal. But the responsible person in Bucharest wished to get a house in exchange. So it had to be postponed, but is not abandoned - similar to the project of paving the main street." (Interview 5)

\subsection{EU? Fairness!}

The EU's Eastern enlargement has initiated a system change, but even after 25 years the changes are not always satisfying in rural areas. Western companies investing here promote infrastructure and create jobs. Yet, transfer know-how occurs to a very limited extent, salaries remain below average and profits are just partly reinvested in the destination country, but mostly transferred to the head office in the home country. Destination countries of Foreign Direct Investment (FDI) grow in dependency. Compensating measures like cohesion and structural funds do not achieve full compensation according to some economists (e.g. Boros 2014).

Despite of examples like the sewage system in Viscri/Deutsch-Weißkirch, living resilient based on neoliberal rules requires money. A good example is the need for shutting down nuclear power plants all over Europe. This is just possible in countries with financial means to change to more sustainable energy forms. In most postCommunist countries this is not the case.

Fairness within the EU would mean being more sensitive when dealing with the needs of rural areas in certain countries by, e.g., designing mechanisms, which allow them being more independent of the often too selective structural funds. Both reinvestment of the profit in the destination and tax payment where the profit is created would be desirable. These measures would not only increase Gross Domestic Product (GDP), but also Gross National Income (GNI). 


\subsection{Cultural landscapes? Heritage appreciation!}

Cultural landscapes are another issue that have gained relevance in rural development policies. One of the main challenges in this respect is their conservation.

Cultural landscapes need to be preserved both from 'active' threats, i.e. suburbanisation, pollution, soil degradation by human activities, as well as from 'passive' threats - land abandonment and decline of 'traditional' land management. Preservation means keeping landscapes resilient, i.e. able to continuously evolve.

Preserving cultural landscapes cannot work without the local population, since they are part of them. This is usually well-understood by relevant actors in place as expressed by this statement: "After a year we realised that the rich biodiversity is rooted in the traditional land management." (Interview 3)

It is, however, also obvious that the inherited cultural landscape cannot be preserved as it is. Thus, it is impossible to cultivate the numerous field terraces shaped by secular human intervention like those at the slopes of the Szeklers' Rock near Rimetea/Torockó in the traditional way. But economic abandoning of a cultural landscape does not necessarily mean its complete disappearance, if landscapes are understood both in their material and non-material dimension or, in other words, as the product of a double artialisation process (Roger 1997) consisting of "in situ" artialisations (i.e. manmade, 'physical' transformation of the territory during history) and "in visu" artialisations (i.e. the cultural meaning of landscapes being connoted by artistic narratives, including graphic representations, literature, but also other ways of expression related to 'popular' culture).

A cultural landscape gradually disappearing may therefore remain as an intangible heritage if people keep it alive at least in a non-material sense. In this context locals have a key role by creating landscape narratives. They need, however, appreciation both from peers and external actors, including public administration. Mainly the latter is often missing, not only in Romania, but also, e.g., in the Spanish Pyrenees (SANCHO REINOSo 2011). Issues like identity play a crucial role in this respect.

\subsection{Spatial planning? Subsidiarity principle!}

To give bottom-up development strategies in rural areas a real chance, an implementation of empirically measurable, spatially functional interactive localities has to take place. These localities should be attributed to NUTS-2 regions to ensure that a truly operational spatial structure is built. This implementation, which necessarily includes spatial planning issues, represents a great challenge in a highly centralised country like Romania, basically for two reasons: (1) heterogeneity of cultures, ethnic groups and structures; and (2) high spatial disparities regarding many variables, including income (Fig. 2). 
Figure 2: GDP per capita by counties, 1994 (a) and 2005 (b)

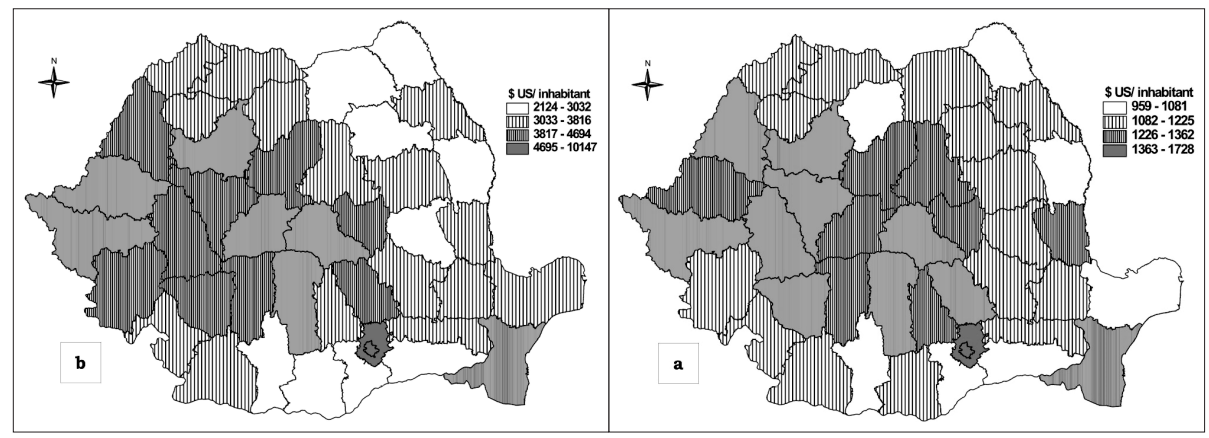

Source: IANOŞ 2010

A regionalisation process usually needs a long-term discussion including power struggles between the local, regional and national elites. In Romania, such a process started after the fall of the Iron Curtain, so it is going on for over 25 years now.

Regarding spatial policies and spatial planning, the subsidiarity principle should play a decisive role when proceeding towards a more balanced administrativeterritorial system. The Strategic Concept of Spatial Development "Romania 2030" (SCSD) and its implementation process show how the subsidiarity principle and other European Union strategies are dealt with in order to obtain structural funds from the EU. This document is the first in the history of the Republic of Romania that (1) deals with territorial issues of any kind, (2) states goals for the spatial development towards EU standards, and (3) gives evidence for respecting localities, regions and their entrepreneurs by adapting the strategy with a bottom-up approach.

According to statements made by the former Secretary of State for Regional Policy, István Csutak, during a phone interview conducted by one of the authors in 2012, the implementation of the SCSD is, however, taking place without participation of any local or regional civil organisation; the document itself is not legally binding in order to guarantee political will to reach its goals; and it was developed mostly to fulfil the expectations of the European Commission in order to obtain structural funds.

Taking these statements into account, the document's ten strategic objectives become somehow blurred. We nevertheless highlight three of the ten goals related to rural areas and rural development: "Asserting urban-rural solidarity" (Objective 4), "Rural development" (Objective 5) and "Protecting, developing and valuing the cultural and natural heritage" (Objective 9). 


\section{Conclusion and further steps}

The eight proposals developed in this paper compound a vision that could become part of a wider programme of societal and territorial transformation in rural areas in Eastern Europe. This programme cannot be realised only partially, but needs realisation in its whole, and this gives to this paper's scope an ambitious and comprehensive character. It is a kind of vision that has to be gradually implemented, corresponds to a long-term perspective.

It is apparent that this programme cannot be developed within the current social, cultural and economic paradigm, which is mostly determined by top-down approaches, where governments are supposed to take both the initiative and the lead when managing the common good. The hurdle that might become the most difficult to overcome is the discourse of growth as the only way of development, although a number of scholars and non-academic stakeholders, even governmental initiatives ${ }^{12}$ have been arguing that this paradigm will become obsolete anyway.

The ultimate goal of this programme is to contribute to proceed towards reaching the common good as a way to increase individuals' and communities' well-being. One of the questions posed in every focus-group discussion was whether the locals feel happier now than ten years ago. In many cases the answer was "yes". To maintain this short-term positive effect of initiatives already on track, communities in such challenged areas have to discover their power to participate and communicate their needs and views about the function and value of rural areas, to develop into 'civil societies'.

Returning to the initial hypothesis and taking into account the ideas presented and the arguments developed in Chapter 2, the authors argue that, in order to become 'smart', rural areas have to increase their resilience. To do so (and following the paper's main argument), they necessarily need to pay attention to the local scale. Keeping the immediate (human and natural) environment as the primary reference when producing basic goods (and particularly food), when addressing both daily and extraordinary matters, when socializing, when generating economic activity and when dealing with waste, will ultimately make rural areas (and living conditions of those who live there) more authentic.

\footnotetext{
12 In this respect, the initiative "Wachstum im Wandel" ("Growth in Transition"), started by the Austrian Federal Ministry of Agriculture, Forestry, Environment and Water Management in 2008, has to be highlighted as a pro-active attitude from the central authorities in a Western European democracy. Further details on http://www.growthintransition.eu/.
} 


\section{References}

Boros I. (2014), Árulkodó háttérképek pénzügyekröl. Budapest, Kairosz.

Boulanger P.-M. (2010), Three strategies for sustainable consumption. In: Sapiens, 3, $2<$ http:// sapiens.revues.org/1022\#tocto1n4>

BRAND U., BRUNNENGRÄBER A. (2013), Debating transformation in multiple crises. In: UNESCO, ISSC, OECD (eds.), World Social Science Report 2013: Changing global environments, p. 480-484. Paris.

Del Moral L. (2012), Crisis del capitalismo global y medio ambiente. In: Spanish Delegation Aт тHE IGU (ed.), Nuevos aires en la geografía Española del s.XX/New trends in the XXI century Spanish geography, pp. 56-70. Madrid, Spanish Geographers Association (AGE).

Fischer-Kowalski M., Haberl H., Hüttler W., Payer H., Schandl H., Winiwarter V., ZangerlWeIsz H. (1997), Gesellschaftlicher Stoffwechsel und Kolonisierung von Natur: Ein Versuch in Sozialer Ökologie. Amsterdam, G+ B Verlag Fakultas.

Giffinger R., Fertner C., Kramar H., Kalasek R., Pichler-Milanovic N., Meijers E. (2007), Smart Cities - Ranking of European medium-sized cities. Vienna, Vienna University of Technology $<$ http://curis.ku.dk/ws/files/37640170/smart_cities_final_report.pdf $>$

Glöckner J., KovÁcs E. (2012), Die strategische Planung Rumäniens. University of Vienna [unpublished seminar project].

HeinBerg R. (2007), Peak Everything. Waking up to the century of declines. Gabriola Island, New society.

Ianoş I. (2010), Spatial Pattern of Romania's Uneven Territorial Development. In: Revista Română de Geografie Politică, XII, 1, pp. 5-17.

Ilbery B., Bowler I. (1998), From agricultural productivism to post-productivism. In: Ilbery B. (ed.), The Geography of Rural Change, pp. 57-84. London, Longman.

JACKSON T. (2009), Prosperity without Growth. Economics for a finite planet. London, Earthscan -Routledge.

Lapping M. (2006), Rural policy and planning. In: Cloke P., Mardsen T., Mooney P. (eds.), The handbook of rural studies, pp. 104-122. London, SAGE.

Meadows D.H., Meadows D.L., Randers J., Behrens W. (1972), The limits to growth. New York, Universe Books.

Ministry of Development, Public Works and Housing (ed.) (2008), Strategic concept of territorial development - Romania 2030; Romania a competitive, balanced and prosperous country. Excerpt - Public consultation document. Bucharest: Ministry of Development, Public Works and Housing <http://www.espon-interstrat.eu/admin/ attachments/20110317231022_Brochure_ROU_SCTDR_EN.pdf>

Roger A. (1997), Court traité du paysage. Paris, Gallimard.

SAncho Reinoso A. (2011), Rural change, landscape transformation and territorial policies in La Terreta (Spanish Pyrenees). English shortened version. PhD. thesis, University of Barcelona.

Schumacher E.F. (1973), Small is beautiful: A study of economics as if people mattered. London, Blond \& Briggs. 
Wieland A., Wallenburg C.M. (2013), The Influence of Relational Competencies on Supply Chain Resilience: A Relational View. In: International Journal of Physical Distribution \& Logistics Management, 43, 4, pp. 300-320.

Wiesinger G. (2007), L'importance du capital social dans le développement rural, les réseaux et les prises de decision dans les zones rurales. In: Revue de Géographie Alpine/Journal of Alpine Research, 95, 4, pp. 29-42.

World ENERGY COUNCIL (ed.) (2008), Europe's vulnerability to energy crisis.London, WorldEnergy Council <http://www.worldenergy.org/wp-content/uploads/2012/10/PUB_Europes_ Vulnerability_to_Energy_Crisis_2008-WEC.pdf>

\section{Interview partners:}

Interview 1: Project director of the Transylvania Trust

Interview 2: Vice-mayor of Rimetea/Torockó

Interview 3: Representative of ADEPT

Interview 4: Mayor of Bunesți

Interview 5: Tourism and social initiator in Viscri/Deutsch-Weißkirch

Interview 6: Pupil from Rimetea/Torockó

\section{Focus-group discussions:}

Focus group discussion 1: Rimetea/Torockó

Focus group discussion 2: Viscri/Deutsch-Weißkirch

Focus group discussion 3: Marginea 